\title{
Pterygium surgery by means of conjunctival autograft: long term follow-up
}

\author{
Cirurgia de pterígio por meio de transplante autólogo de conjuntiva: acompanhamento a longo prazo
}

\author{
Valentín Huerva ${ }^{1}$, Anna March ${ }^{1}$, Montserrat Martinez-Alonso², M. Jesús Muniesaª ${ }^{1}$, Carmen Sanchez ${ }^{1}$
}

\section{ABSTRACT}

Purpose: To demonstrate the long term of follow-up of the recurrence rate after conjunctival autograft for pterygium surgery.

Methods: A total of 112 patients operated for pterygium with conjunctival autografts and with more than one year follow-up were registered. Patients were called for voluntary examinations of their respective ocular surface statuses. Completing the study was only possible in 44 cases. Seven had bilateral pterygium. ( $N=51$ operated pterygium).

Results: The mean follow-up time was 49.06 months. In $29.45 \%$ of the cases, attachment was performed using non-absorbable sutures (nylon 10/0), while fibrin glue was used in $70.55 \%$ of the cases. Six cases of recurrence $(11.76 \%$ ) were found. The recurrence rate between primary and recurrent pterygium, and between sutures and fibrin glue proved to be not statistically significant; $p>0.05$. There were no significant differences between women and men with respect to recurrence. The median of age in the recurrence group was 40 years old, in contrast to 55 in the non-recurrence group; $p=0.01517$. All of these recurrences were associated with patients of Hispanic origins (from Latin America); $\mathrm{p}=0.001506$.

Conclusions: After a long follow-up period after autograft pterygium surgery, there were no statistically significant differences in recurrence rates for the application of sutures as opposed to fibrin glue; similarly, there were no statistically significant differences between the use of autograft in primary and recurrent pterygium. The greatest risk factors for recurrence were young age and Hispanic ethnicity.

Keywords: Pterigium/surgery; Transplantation, autologous; Conjunctiva/transplantation, Sutures; Fibrin tissue adhesive

\section{RESUMO}

Objetivo: Demonstrar a taxa de recorrência em cirurgia do pterígio com transplante autólogo de conjuntiva após um acompanhamento a longo prazo.

Métodos: Cento e doze pacientes operados de pterígio e transplante autólogo de conjuntiva, com mais de um ano de acompanhamento foram registrados. Os pacientes foram chamados para um exame voluntário de estado da superfície ocular. O estudo completo só foi possível em 44 pacientes. Sete deles tinha tido pterígio bilateral. ( $\mathrm{N}=51)$.

Resultados: A média de acompanhamento a partir do momento da cirurgia até o exame foi de 49,06 meses. A sutura não-absorvível (nylon 10/0) foi usada em 29,45\% dos casos, enquanto que a cola biológica de fibrina foi usada em $70,55 \%$. A recidiva do pterígio foi detectada apenas em 6 casos $(11,76 \%)$. As recidivas entre pacientes operados de pterígio primário e recorrente, e entre o uso de suturas ou cola de fibrina não foram significativos ( $p>0,05)$. Também não houve diferença significativa na recorrência com relação ao sexo. A idade média no grupo de recidiva foi de 40 anos e no grupo sem recidiva de 55 anos ( $\mathrm{p}=0,01517)$. Todas essas recorrências ocorreram em pacientes de origem hispânica (América latina) $(p=0,001506)$.

Conclusões: A longo prazo da remoção cirúrgica de pterígio utilizando um transplante autólogo de conjuntiva, não há diferença estatisticamente significativa com o uso de sutura ou cola de fibrina. Também não há diferenças na recidiva, se o transplante autólogo de conjuntiva utilizado for em casos primários ou recorrentes de pterígio. O maior fator de risco para a recorrência parece estar entre os jovens e pacientes de etnia hispânica.

Descritores: Piterigio/cirurgia; Transplante autólogo; Conjuntiva/transplante; Suturas; Adesivo tecidual de fibrina

\section{INTRODUCTION}

Suturing an ipsilateral conjunctival autograft to cover the naked scleral bed after pterygium excision makes it possible to recreate the normal architecture of the limbus and has been associated with low rates of recurrence ${ }^{(1,2)}$. The oldest description of conjunctival autograft for pterigium surgery date of the sixties ${ }^{(3,4)}$. The cut and paste technique for pterygium surgery was first reported by Kenyon et al. in $1985^{(5)}$. Free conjunctival grafts from the superotemporal bulbar conjunctiva of the same eye were used to resurface the exposed sclera and extraocular muscle ${ }^{5}$. Koranyi et al. ${ }^{(6)}$ in 2004 were the first to report the use of fibrin glue for conjunctival grafting in pterygium surgery. In a prospective randomized clinical study, they took an autologous conjunctival graft from the superotemporal limbus and used it to cover the sclera after pterygium excision. This graft, which was made in 20 patients, was then attached to the sclera with fibrin glue. These authors subsequently concluded that using fibrin glue instead of sutures when attaching conjunctival grafts in pterygium surgery causes significantly less postoperative pain and complaints and significantly shortens surgery time. The major challenge after pterygium surgery is then to prevent pterygium recurrence.

Various different studies have compared the safety and recurrence rates of pterygium associated with the use of absorbable and non-absorbable sutures and the use of sutures and fibrin glue when making conjunctival autografts ${ }^{(7-18)}$. All of these studies concluded that the use of fibrin glue in pterygium surgery involving conjunctival autografting significantly reduces surgery time and improves postoperative patient comfort and cosmesis. Even so, there was no such consensus with respect to the question of recurrences and unfortunately, the recurrence rate was not evaluated in many of
Funding: No specific financial support was available for this study Disclosure of potential conflicts of interest: V.Huerva, None; A.March, None; M.Martinez-Alonso, None; M.J.Muniesa, None; C.Sanchez, None.

Correspondence address: V. Huerva. Department of Ophthalmology, University Hospital Arnau de Vilanova. Avda. Rovira Roure, 80 - Lleida - Spain - 25198 - E-mail: vhuerva@gmail.com 
these studies $(7,9,10,14,16,18)$. Some studies did, however, demonstrate lower rates of recurrence when fibrin glue was used ${ }^{(8,13)}$, while in others, the same rate of recurrence was reported as associated with suturing $(10,11,15-17)$. The majority of these studies did not have long follow-up times. The longest series published after using fibrin glue showed a mean recurrence percentage of $4.50 \%$ in a series of 111 operated cases of pterygium during a two-year follow-up ${ }^{(19)}$.

Associated epidemiological factors such as age, gender and race may have influenced the possibility of recurrence after this type of pterygium treatment ${ }^{(20-22)}$. The aim of this study was to observe the recurrence rate after a conjunctival autograft associated with pterygium surgery in cases treated with both sutures and fibrin glue during a long-term follow-up and to demonstrate whether some epidemiologic factors could be associated with recurrence.

\section{METHODS}

A retrospective study was carried out involving a total of 112 patients whose pterygium had been operated. All of these patients had undergone operations at least one year before, which had consisted of conjunctival autografts to cover the sclera and had been conducted at the ocular surface unit of the Ophthalmology Department of the "Arnau de Vilanova" University Hospital, Lleida, Spain. Thirteen of these patients had had bilateral pterygium surgery. Personal and clinical data from the patients'clinical histories were also analyzed. The surgical procedure was carried by the first and the last author. The study was approved by the hospital's Ethical Committee/ Investigational Review Board.

\section{SURGICAL TECHNIQUE}

The surgical approach adopted was similar to others that have been previously reported ${ }^{(19,22)}$ : in each case, peribulbar anesthesia and sedation were administered and a lid speculum was used. The keratinized head of the pterygium was dissected from the cornea up to the limbal margin and excised using Wescott scissors. The fibrovascular tissue underlying the pterygium was then exposed by a blunt and sharp dissection, up to the point of insertion of the medial rectus muscle, and then excised. The corneal bed of the pterygium was scraped with a crescent knife and then any bleeding vessels were cauterized. The dimensions of the scleral bed were measured using calipers and a free graft was then obtained from the ipsilateral superotemporal bulbar conjunctiva. Care was taken not to include Tenon tissue when preparing the graft. The separation of the conjunctiva of the Tenon was carried by means of subconjunctival injection of serum or a local anesthetic. The dissection of conjuctival tissue was performed with Wescott scissors. The graft was sutured to the conjunctiva and scleral bed with 10/0 interrupted nylon sutures. In other cases, fibrin glue (Tissucol Duo ${ }^{\circledR}$, Baxter AG, Vienna, Austria) was used to attach the autograft to the scleral bed. The two components were applied separately: 1 drop of the fibrinogen component was placed on the scleral bed and then 1 drop of the thrombin component was applied to the stromal surface of the conjunctiva to activate the polymerization process from the moment that the autograft made contact with the scleral bed. The criteria of receiving suture or fibrin glue was not randomized between the two groups. Sutures were utilized in the older cases previously to the introduction of the fibrin glue for the pterygium surgery. The characteristics of the pterygium and the surgical indications were similar in cases operated with sutures and in cases operated with fibrin glue.

Dexamethasone and tobramycin eye drops (Tobradex ${ }^{\circledR}$, Alcon Laboratories, 6201 South Freeway Fort Worth, Texas, United States) were administered 4 times per day, with a progressive reduction during the first month. Non-absorbable sutures were removed two weeks after surgery. The follow-up continued for between 6 months and one year, until definitive discharge.

\section{METHODS}

The 112 registered patients were called for a voluntary examination of their ocular surface status. Patient localization and conduction of a complete study were only possible in 44 cases. Seven of these patients had bilateral pterygium and had had both eyes operated on. It was therefore finally possible to base the study on 51 of the operated pterygium. It was not possible to study the rest of the patients due to a variety of circumstances that included changes of telephone number, address, and/or country of residence or their unwillingness to take part in the study. The demographic characteristics of the 51 eyes examined are presented in table 1.

Ocular surface integrity was evaluated by slit-lamp biomicroscopy. Side effects and complications, which were observed in some cases and included: granuloma formation, autograft retraction and partial scleral exposure were not considered in the statistical study. Recurrence was notified for any growth of conjunctival tissue on the cornea. Only these data were chosen for the statistical study.

We perform a search in Pubmed database for the comparation of previous recurrence rate published reports. The Key Words for the search were: pterygium surgery, pterygium recurrence, conjunctival autograft, fibrin glue, sutures.

\section{Statistical study}

First, a descriptive statistic of the study population study was made (Table 1). Bivariate analysis was used to establish the risk of recurrence. The Wilcoxon rank sum test with continuity correction and Fisher's Exact Test for count data were used $(p<0.05)$ and the free software $R$ was used for statistical analysis. (R Development Core Team 2011. R: A language and environment for statistical computing. R Foundation for Statistical Computing, Vienna, Austria. ISBN 3-900051-07-0, URL http:// www.R-project.org/).

\section{RESULTS}

The 51 eyes with pterygium that completed the study were operated on by excision and conjunctival autograph, with a mean follow-up time of 49.06 months (+/- 32.57) and a median follow-up time of 46.45 months. In $29.45 \%$ (n: 14) of cases, attachment was performed using non-absorbable sutures (nylon 10/0) and in $70.55 \%$ (n: 37) using fibrin glue. In total, 6 cases of recurrence $(11.76 \%)$ were observed: 4 after sutures and 2 after fibrin glue. $66.66 \%$ of the recurrences were observed in primary pterygium and $33.34 \%$ in recurrent pterygium. The recurrence rates between primary and recurrent pterygium and between using sutures and fibrin glue were not statistically significant: Fisher test, $p>0.05$. The results for gender were also non-significative. Four recurrences occurred in men and two in

Table 1. Demographic characteristics of the follow-up of 51 cases of operated pterygium

\begin{tabular}{lcccc}
\hline Age (years) & Gender & Race & $\begin{array}{c}\text { Primary/recurrent } \\
\text { pterygium }\end{array}$ & $\begin{array}{c}\text { Follow-up } \\
\text { (months) }\end{array}$ \\
\hline Mean: 55.74 & $\begin{array}{c}\text { Male: } \\
\text { (m) }(64.71 \%)\end{array}$ & $\begin{array}{c}\text { White } \\
\text { Spanish: } \\
\text { 30 (58.82\%) }\end{array}$ & $\begin{array}{c}\text { Primary: } \\
\text { (3) }(84.31 \%)\end{array}$ & Mean: 49.06 \\
Std Dev: 16.12 & $\begin{array}{c}\text { Female: } \\
\text { Hispanic: }\end{array}$ & $\begin{array}{c}\text { Recurrent: } \\
\text { 18(35.29\%) }\end{array}$ & Std Dev: 32.57 \\
Min: 23 & & North-African: & & Min: 12 \\
Max: 82 & & $2(3.92 \%)$ & Max: 130.9 \\
Median: 54 & & & Median: 46.45
\end{tabular}

Follow-up time between surgery and examination. 
women. The median of age in the recurrence group was 40 years old as opposed to 55 in the non-recurrent group. The Wilcoxon rank sum test result was significant: p: 0.01517. All of these recurrences occurred in Hispanic patients (originating from Latin America); Fisher test, p: 0.001506.

The table 2 shows the published data after a systematic analysis about pterygium recurrence after surgery using a conjunctival autograft.

\section{DISCUSSION}

The treatment of ocular pterygium has been subject to the development and application of various new strategies in recent years. The worrisome problem of recurrence seems to have been significantly reduced with the newer methods of treatment. However, this field is still evolving, although excision and adjunctive treatment with mitomycin C or conjunctival autograft is currently the most accepted and popular way of treating both primary and recurrent pterygium ${ }^{(23)}$. The surgeon's skill and experience may affect the recurrence rate, which can range from $2 \%$ to $39 \%$ in the case of a conjunctival autograft ${ }^{(24,25)}$. Nevertheless, even in the most experienced hands, graft suturing has the disadvantage of requiring longer surgical time than the bare sclera technique. It also carries the implicit risk of complications, such as granuloma formation, and significant patient discomfort after surgery, associated with exposed

Table 2. Systematic analysis about pterygium recurrence after surgery using a conjunctival autograft

\begin{tabular}{|c|c|c|c|c|c|}
\hline Autor/year & Type of study & № of patients & Tecniques compared & Follow-up period & Recurrence rate \\
\hline Uy et al., $2005^{(7)}$ & Randomized clinical trial & 22 & $\begin{array}{l}11 \text { cases fibrin glue } \\
11 \text { cases sutures }\end{array}$ & 2 months & Non reported \\
\hline Lani et al., 2005(38) & Prospective study & 230 & $\begin{array}{l}\text { Conjuntival autograft. } \\
\text { Non comparative }\end{array}$ & 1-year & $2.17 \%$ \\
\hline Koranyi et al., 2005 ${ }^{(31)}$ & $\begin{array}{c}\text { Retrospective } \\
\text { comparative study }\end{array}$ & $\begin{array}{c}381 \\
\text { (461 eyes) }\end{array}$ & $\begin{array}{l}325 \text { cases with fibrin glue } \\
136 \text { reabsorvable sutures }\end{array}$ & 6-112 months & $\begin{array}{l}5.3 \% \text { with fibrin glue } \\
13.5 \text { with sutures }\end{array}$ \\
\hline Bahar et al., 2006(8) & Randomized clinical trial & 65 & $\begin{array}{l}39 \text { fibrin glue } \\
26 \text { vicryl sutures }\end{array}$ & 21 days & Non reported \\
\hline Wong et al., 2007(9) & $\begin{array}{l}\text { Randomized } \\
\text { clinical trial }\end{array}$ & 32 & Nylon/polyglactin sutures & 3 months & Non reported \\
\hline Bahar et al., 2007(10) & $\begin{array}{l}\text { Randomized } \\
\text { clinical trial }\end{array}$ & 81 & $\begin{array}{l}42 \text { fibrin glue } \\
39 \text { vicryl sutures }\end{array}$ & 1 year & $\begin{array}{l}\text { 11.9\% with fibrin glue } \\
7.7 \% \text { with vicryl }\end{array}$ \\
\hline Jiang et al., 2008(11) & $\begin{array}{c}\text { Prospective, } \\
\text { comparative case series }\end{array}$ & 40 & $\begin{array}{l}20 \text { fibrin glue } \\
20 \text { nylon 10/0 }\end{array}$ & 1 year & $\begin{array}{l}5 \% \text { with fibrin glue } \\
10 \% \text { with nylon } 10 / 0\end{array}$ \\
\hline Ozdamar et al., 2008(12) & $\begin{array}{c}\text { Prospective, } \\
\text { comparative case series }\end{array}$ & 24 & $\begin{array}{l}12 \text { fibrin glue } \\
12 \text { vicryl sutures }\end{array}$ & 6 months & $0 \%$ in both grups \\
\hline Ayala 2008(22) & $\begin{array}{l}\text { Prospective non } \\
\text { randomized trial }\end{array}$ & 88 & $\begin{array}{c}\text { Fibrin glue } \\
\text { (non comparative) }\end{array}$ & 1 year & $4.54 \%$ \\
\hline Karalezli et al., 2008(13) & $\begin{array}{l}\text { Randomized } \\
\text { clinical trial }\end{array}$ & 50 & $\begin{array}{l}25 \text { fibrin glue } \\
25 \text { vicryl sutures }\end{array}$ & 1 year & $\begin{array}{l}4 \% \text { with fibrin glue } \\
12 \% \text { with fibrin glue }\end{array}$ \\
\hline Srinivasan et al., 2009.(14) & $\begin{array}{l}\text { Prospective, observer } \\
\text { masked, clinical trial }\end{array}$ & 40 & $\begin{array}{l}20 \text { fibrin glue } \\
20 \text { sutures }\end{array}$ & 3 months & Non reported \\
\hline Farid et al., 2009(15) & Retrospective study & $\begin{array}{c}47 \\
\text { (42 patients) }\end{array}$ & $\begin{array}{c}27 \text { fibrin glue } \\
20 \text { absorvable sutures }\end{array}$ & 22-36 months & $\begin{array}{l}3.7 \% \text { with fibrin glue } \\
20 \% \text { with sutures }\end{array}$ \\
\hline Miranda-Rollón et al., 2009(16) & $\begin{array}{c}\text { Prospective, } \\
\text { comparative case series }\end{array}$ & 17 & $\begin{array}{c}8 \text { fibrin glue } \\
9 \text { absorvable sutures }\end{array}$ & Not clear & $\begin{array}{l}\text { Only } 1 \text { case in group of } \\
\text { fibrin glue (12.5\%) }\end{array}$ \\
\hline Hall et al., $2009^{(17)}$ & Randomized clinical trial & 50 & $\begin{array}{l}25 \text { fibrin glue } \\
25 \text { vicryl }\end{array}$ & 1-year & $\begin{array}{l}0 \% \text { with fibrin glue } \\
4 \% \text { with vicryl }\end{array}$ \\
\hline Ratnalingam et al., 2010 & Randomized clinical trial & 137 & $\begin{array}{l}68 \text { fibrin glue } \\
69 \text { sutures }\end{array}$ & 1 year & $\begin{array}{l}4.41 \% \text { with fibrin glue } \\
15.9 \text { with sutures }\end{array}$ \\
\hline Hirst, $2009^{(35)}$ & $\begin{array}{c}\text { Prospective in recurrent } \\
\text { Perigium }\end{array}$ & 111 & $\begin{array}{c}\text { Fibrin glue } \\
\text { (non comparative) }\end{array}$ & 1-year & $0 \%$ \\
\hline Sarnicola et al., 2010 ${ }^{(19)}$ & Retrospective series & 100 & $\begin{array}{c}\text { Fibrin glue } \\
\text { (non comparative) }\end{array}$ & 2-years & $4.5 \%$ \\
\hline Coral-Ghanem, 2010 & $\begin{array}{l}\text { Prospective and } \\
\text { retrospective series }\end{array}$ & $\begin{array}{l}100 \\
51\end{array}$ & $\begin{array}{l}106 \text { eyes fibrin glue } \\
58 \text { eyes sutures }\end{array}$ & 5 months at leats & $\begin{array}{l}11.3 \% \text { with fibrin glue } \\
25.9 \% \text { with sutures }\end{array}$ \\
\hline Nieuwendaal et al., $2011^{(32)}$ & Retrospective case series & 35 & $\begin{array}{c}\text { Fibrin glue } \\
\text { (non comparative) }\end{array}$ & 1 year at least & $2.9 \%$ \\
\hline Rubin et al., 2011 $1^{(27)}$ & Randomized clinical trial & 47 & $\begin{array}{l}21 \text { (fibrin glue) } \\
26 \text { nylon 10/0 }\end{array}$ & 6 months & $\begin{array}{l}4.76 \% \text { with fibrin glue } \\
7.69 \% \text { with sutures }\end{array}$ \\
\hline Pan et al., $2011^{(28)}$ & Meta-analisis (7 studies) & 342 & Fibrin glue/sutures & 2-12 months & $\begin{array}{l}\text { No significant difference } \\
\text { in } 4 \text { studies }\end{array}$ \\
\hline
\end{tabular}


suture ends and the need for suture removal if non-absorbable stitches are used ${ }^{(26)}$. Both polyglactin and nylon are effective suture materials for autograft suturing in pterygium surgery and cause comparable postoperative discomfort ${ }^{(9)}$. However, polyglactin sutures caused slightly more conjunctival reactions in the early postoperative period than nylon sutures. The use of fibrin glue for attaching the conjunctival autograft in the surgical management of primary pterygium reduced surgical time and also conjunctival hyperemia and ocular discomfort compared to fixation with nylon 10/0 or with vicryl sutures; it proved an excellent option for conjunctival autograft attachment in primary pterygium surgery ${ }^{(6-8,10-16,18,22,23,27)}$. Even so, its role with respect to traditional suturing is still a matter of debate. A metanalysis to compare the safety and clinical efficacy of fibrin glue with that of suture for conjunctival autograft attachment in pterygium surgery showed that fibrin glue was associated with significant reductions in operating time and was more effective than suture in reducing the recurrence rate ${ }^{(28)}$. This metanalysis evaluated 342 participants with 366 eyes from 7 studies. The use of fibrin glue can decrease the recurrence rate throught its ability to reduce inflammation. Postoperative inflammation is closely associated with the surgical outcome and the risk of pterygium recurrence ${ }^{(29)}$. The use of sutures may induce inflammation ad migration of Langerhans cells to the cornea ${ }^{(30)}$. A retrospective study ${ }^{(31)}$ and a prospective ${ }^{(14)}$ comparative studies showed statistically significant less degree of inflammation and decreased recurrence rate with fibrin glue use than sutures. The recurrence rate was not evaluated in many of the studies cited in which fibrin glue was used $(7,9,12,14,16,18)$. However, some studies have reported lower rates of recurrence when using fibrin glue ${ }^{(8,13,14,31,32)}$, while others have reported the same rate of recurrence as when using suturing ${ }^{(10,11,15-17,33)}$. The majority of these studies have not been subjected to long time follow-ups and when such studies have been conducted, most of them have focused on periods of less than one year. The longest series published after using fibrin glue showed a mean recurrence of $4.50 \%$ in a series of 111 operated pterygium over a follow-up period of two years ${ }^{(19)}$. Having reviewed the published literature, we have presented the longest conjunctival autograft survival series for both primary and recurrent pterygium surgery. Our cases were operated on with sutures and fibrin glue. The suture cases corresponded to the oldest cases; before that, we used the cut and paste technique ${ }^{(5)}$. The sample sizes may limit the final conclusions on the comparative techniques to prevent the pterygium recurrence ${ }^{(34)}$. In prospective randomized comparative studies it is possible to determine the size of the groups for a statistical significant result. High size of the sample may be obtained by means of a multicentric study. In retrospective studies it is only possible to analyze the results of the well evolutive documented cases. The size of the sample may not be predetermined. The limitation of these studies may be the low size of the comparative groups if the patients belong to one institution. In addition many patients can not be located as previously has been said.

We found an $11.76 \%$ rate of recurrence for these two methods. Our recurrence rate was higher than those observed in previously published long survival series ${ }^{(19)}$ and in line with the expected rates of recurrence reported in other subsequent series involving conjunctival autografts ${ }^{(24,25)}$. Many factors may explain why our rate was higher then the previously published series. First, we analyzed the survival rate in primary and recurrent pterygium; secondly, the follow-up period was twice as long as in previous studies; and thirdly, we considered such epidemiological factors as gender, age and race as potential causes of recurrence. The recurrence rate showed no statistically significant difference between using nylon sutures and fibrin glue as reported in previous studies $s^{(10,11,15-17,33)}$. We share the general consensus that using fibrin glue reduced surgical time and the incidence of conjunctival hyperemia and ocular discomfort during the postoperative period. One of the greatest inconveniences associated with the use of fibrin glue is its price, which may pose a problem in some countries. However, we can conclude that when conjunctival autograft is utilized for pterygium surgery, the expected rate of long term recurrence is the same as with nylon sutures and fibrin glue. Furthermore, we found no statistically significant difference when the conjunctival autograft was performed with primary and recurrent pterygium. This observation also suggests that there may be no need for adjunctive therapies when a conjunctival autograft is used ${ }^{(35)}$. The size and morphology of the pterygium have been correlated with the recurrence rate ${ }^{(19,36)}$. In our study, these factors were not considered because they were not well referenced in clinical histories. Most studies do not record these factors for recurrence, but they may be important. The absence of significant diference in certain analysis may be related to small samples size.

We found more statistical differences for recurrence in individual factors than in clinical aspects of pterygium or relating to the surgical approach employed. Although we found a higher frequency of pterygium in men than in women, there was no significant rate of recurrence between the two genders. However, when we analyzed the recurrence rate with respect to age, our results showed a very significant increase in recurrence in younger patients. 100\% of the recurrences in our series were registered among members of the Hispanic population; this result was statistically significant. This population group, which comes from Latin American countries, is generally younger than that of white Spanish patients affected by pterygium. The frequency of pterygium in these latitudes is particularly high due to increased exposure to sunlight and to factors influenced by their socioeconomic status ${ }^{(20)}$. There is a strong suggestion of a causal relationship between ultraviolet light exposure and the development of pterygia during the early years of life and the cumulative exposure over the next 2 to 3 decades in occupations in which there is a high component of reflected ultraviolet light ${ }^{(37)}$. The risk of pterygium increases among patients who, in their third decade of life, worked outdoors in an environment with high surface reflectance of ultraviolet light compared with those who worked indoors. Those subjects who spent their first 5 years of life at latitudes less than 30 degrees had almost 40 times the risk of pterygium than those living at latitudes greater than 40 degrees; spending the majority of times outdoors in these earliest years was associated with a 20 -fold increase in risk of developing pterygium ${ }^{(37)}$.

Furthermore, fleshiness morphology is more common in this population than in the wider Spanish patient population. These three factors may contribute to the high rate of recurrence found in this group. In the longest of the published follow-up series, ethnicity was not specifically considered ${ }^{(19)}$

A previous study performed in Sweden concluded that nonSwedish individuals had twice the risk of pterygium recurrence than members of the native Swedish population ${ }^{(22)}$. Heavily pigmented individuals probably have a higher recurrence rate than lighter pigmented individuals ${ }^{22} .7 \%$ of the non-Swedish patients were from Chile. A later study confirmed that Hispanic ethnicity is a potentially important risk factor for the recurrence of primary pterygia treated with conjunctival autograft ${ }^{21}$. This study involved a one-year follow-up; the resulting recurrence rate was $40 \%$ in Hispanic patients. In our series, there was also a high percentage of recurrence in this population group $(31.57 \%=6$ of 19). After discarding the Hispanic ethnicity, our rate of recurrence fell to 0 , which was similar to the rates reported in other studies ${ }^{(35)}$.

In conclusion, following a long follow-up period after pterygium surgery conjunctival autografting, there was no difference in the recurrence rate with respect to the use of sutures or fibrin glue. Similarly, there were no differences when autografting was used to treat cases of primary and recurrent pterygium. The most important risk factors for recurrence were young age at the initial presentation of pterygium and Hispanic ethnicity. 


\section{REFERENCES}

1. Allan BD, Short P, Crawford GJ, Barrett GD, Constable IJ. Pterygium excision with conjunctival autografting: an effective and safe technique. Br J Ophthalmol. 1993; 77(11):698-701.

2. Prabhasawat P, Barton K, Burkett G, Tseng SC. Comparison of conjunctival autografts, amniotic membrane grafts, and primary closure for pterygium excision. Ophthalmology. 1997;104(6):974-85.

3. Naib K. Conjunctival graft following excision of recurrent pterygium. Am J Ophthalmol. 1964;58(11):861-2.

4. Picó-Santiago G. Pterygium: Current concepts of etiology and management. Highlights Ophthalmol. 1965:8:247.

5. Kenyon KR, Wagoner MD, Hettinger ME. Conjunctival autograft transplantation for advanced and recurrent pterygium. Ophthalmology. 1985;92(11):1461-70.

6. Koranyi G, Seregard S, Kopp ED. Cut and paste: a no suture, small incision approach to pterygium surgery. Br J Ophthalmol. 2004;88(7):911-4.

7. Uy HS, Reyes JM, Flores JD, Lim-Bon-Siong R. Comparison of fibrin glue and sutures for attaching conjunctival autografts after pterygium excision. Ophthalmology. 2005; 112(4):667-71.

8. Bahar I, Weinberger D, Dan G, Avisar R. Pterygium surgery: fibrin glue versus Vicryl sutures for conjunctival closure. Cornea. 2006;25(10):1168-72.

9. Wong VW, Rao SK, Lam DS. Polyglactin sutures versus nylon sutures for suturing of conjunctival autograft in pterygium surgery: a randomized, controlled trial. Acta Ophthalmol Scand. 2007;85(6):658-61.

10. Bahar I, Weinberger D, Gaton DD, Avisar R. Fibrin glue versus vicryl sutures for primary conjunctival closure in pterygium surgery: long-term results. Curr Eye Res. 2007;32(5):399-405.

11. Jiang J, Yang Y, Zhang M, Fu X, Bao X, Yao K. Comparison of fibrin sealant and sutures for conjunctival autograft fixation in pterygium surgery: one-year follow-up. Ophthalmologica. 2008;222(2):105-11.

12. Ozdamar Y, Mutevelli S, Han U, Ileri D, Onal B, Ilhan O, Karakaya J, Zilelioglu O. A comparative study of tissue glue and vicryl suture for closing limbal-conjunctival autografts and histologic evaluation after pterygium excision. Cornea. 2008;27(5): 552-58.

13. Karalezli A, Kucukerdonmez C, Akova YA, Altan-Yaycioglu R, Borazan M. Fibrin glue versus sutures for conjunctival autografting in pterygium surgery: a prospective comparative study. Br J Ophthalmol. 2008;92(9):1206-10.

14. Srinivasan S, Dollin M, McAllum P, Berger Y, Rootman DS, Slomovic AR. Fibrin glue versus sutures for attaching the conjunctival autograft in pterygium surgery: a prospective observer masked clinical trial. Br J Ophthalmol. 2009;93(2):215-18.

15. Farid M, Pirnazar JR. Pterygium recurrence after excision with conjunctival autograft: a comparison of fibrin tissue adhesive to absorbable sutures. Cornea. 2009;28(1):43-5.

16. Miranda-Rollón MD, Pérez-González LE, Sentieri-Omarrementería A, Martínez-Rodrí guez R, Parente-Hernández B, Junceda-Moreno J. [Pterygium surgery: comparative study of conjunctival autograft with suture versus fibrin adhesive]. Arch Soc Esp Oftalmol. 2009;84(4):179-84. Spanish.

17. Hall RC, Logan AJ, Wells AP. Comparison of fibrin glue with sutures for pterygium excision surgery with conjunctival autografts. Clin Experiment Ophthalmol. 2009, 37(6):584-9.
18. Ratnalingam V, Eu AL, Ng GL, Taharin R, John E. Fibrin adhesive is better than sutures in pterygium surgery. Cornea. 2010;29(5):485-9.

19. Sarnicola V, Vannozzi L, Motolese PA. Recurrence rate using fibrin glue-assisted ipsilateral conjunctival autograft in pterygium surgery: 2-year follow-up. Cornea. 2010;29(11):1211-4

20. West S, Muñoz B. Prevalence of pterygium in Latinos: Proyecto VER. Br J Ophthalmol. 2009:93(10):1287-90.

21. Kandavel R, Kang JJ, Memarzadeh F, Chuck RS. Comparison of pterygium recurrence rates in Hispanic and white patients after primary excision and conjunctival autograft. Cornea. 2010;29(2):141-15.

22. Ayala M. Results of pterygium surgery using a biologic adhesive. Cornea. 2008; 27(6):663-7.

23. Mohammed I. Treatment of pterygium. Ann Afr Med. 2011;10(3):197-203.

24. Hirst LW. The treatment of pterygium. Surv Ophthalmol. 2003;48(2):145-80

25. Ang LP, Chua JL, Tan DT. Current concepts and techniques in pterygium treatment. Curr Opin Ophthalmol. 2007;18(4):308-13.

26. Starck T, Kenyon KR, Serrano F. Conjunctival autograft for primary and recurrent pterygia: surgical technique and problem management. Cornea. 1991:10(3):196-202.

27. Rubin MR, Dantas PE, Nishiwaki-Dantas MC, Felberg S. Efficacy of fibrin tissue adhesive in the attachment of autogenous conjuntival graft on primary pterygium surgery. Arq Bras Oftalmol. 2011;74(2):123-6.

28. Pan HW, Zhong JX, Jing CX. Comparison of fibrin glue versus suture for conjunctival autografting in pterygium surgery: a meta-analysis. Ophthalmology. 2011; 118(6):1049-54.

29. Ti SE, Tseng SC. Management of primary and recurrent pterygium using amniotic membrane transplantation. Curr Opin Ophthalmol. 2002;13(4):204-12.

30. Hirst LW, Sebban A, Chant D. Pterygium recurrence time. Ophthalmology 1994; 101(4):755-8

31. Koranyi G, Seregard S, Kopp ED. The cut-and-paste method for primary pterygium surgery: long-term follow-up. Acta Ophthalmol Scand. 2005;83(3):298-301.

32. Nieuwendaal CP, van der Meulen IJ, Mourits M, Lapid-Gortzak R. Long-term follow-up of pterygium surgery using a conjunctival autograft and Tissucol. Cornea. 2011; 30(1):34-6.

33. Coral-Ghanem R, Oliveira RF, Furlanetto E, Ghanem MA, Ghanem VC. Conjunctival autologous transplantation using fibrin glue in primary pterygium. Arq Bras Oftalmol. 2010;73(4):350-3.

34. Singh G, Wilson MR, Foster CS. Long-term follow-up study of mitomycin eye drops as adjunctive treatment of pterygia and its comparison with conjunctival autograft transplantation. Cornea. 1990;9(4):331-4.

35. Hirst LW. Recurrent pterygium surgery using pterygium extended removal followed by extended conjunctival transplant. Recurrence rate and cosmesis. Ophthalmology. 2009;116(7):1278-86.

36. Tan DT, Chee SP, Dear KB, Lim AS. Effect of pterygium morphology on pterygium recurrence in a controlled trial comparing conjunctival autografting with bare sclera excision. Arch Ophthalmol. 1997;115(10):1235-40.

37. Mackenzie FD, Hirst LW, Battistutta D, Green A. Risk analysis in the development of pterygia. Ophthalmology. 1992;99(7):1056-61.

38. Lani AH, Lani LA. [Conjunctival autograft transplantation in primary pterygium]. Arq Bras Oftalmol. 2005;68(1):99-102. Portuquese. 